\title{
Oropharyngeal Cancer pTX TNM Finding v6 and v7
}

National Cancer Institute

\section{Source}

National Cancer Institute. Oropharyngeal Cancer pTX TNM Finding v6 and v7. NCI

Thesaurus. Code C64437.

Oropharyngeal cancer in which the primary tumor cannot be assessed. (from AJCC 6th and 7th Eds.) 